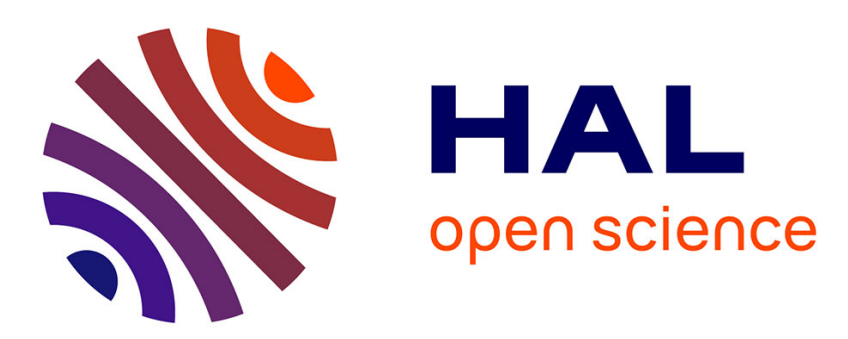

\title{
Romanian epistemic indefinites
}

\author{
Anamaria Falaus
}

\section{To cite this version:}

Anamaria Falaus. Romanian epistemic indefinites. Luis Alonso-Ovalle and Paula Menéndez-Benito. Epistemic Indefinites: Exploring Modality Beyond the Verbal Domain, Oxford University Press; Oxford University Press, pp.60-81, 2015, 978-0-19-966529-7. 10.1093/acprof:oso/9780199665297.003.0003 . hal-01162525

\section{HAL Id: hal-01162525 \\ https://hal.science/hal-01162525}

Submitted on 24 Dec 2020

HAL is a multi-disciplinary open access archive for the deposit and dissemination of scientific research documents, whether they are published or not. The documents may come from teaching and research institutions in France or abroad, or from public or private research centers.
L'archive ouverte pluridisciplinaire HAL, est destinée au dépôt et à la diffusion de documents scientifiques de niveau recherche, publiés ou non, émanant des établissements d'enseignement et de recherche français ou étrangers, des laboratoires publics ou privés. 


\title{
Romanian Epistemic Indefinites*
}

\author{
Anamaria Fălăuș \\ Pre-final draft, March 2014
}

\section{Introduction}

Epistemic indefinites (EIs) ${ }^{1}$ are typically defined as existentials that convey speaker ignorance/indifference or agent indifference with respect to the referent of the indefinite. Romanian has two such items, vreun and un oarecare, illustrated in (1):

A: Who was at the door?

a. $\mathrm{B}: \mathrm{Nu}$ știu, nu am deschis. $\mathrm{O}$ fi fost vreun vânzător. NEG know.1SG NEG have.1SG open FUT2.3SG BE been VREUN salesman 'I don't know, I didn't open. It might have been some salesman.'

b. B: Un vânzător oarecare, unul foarte insistent.

a salesman OARECARE one.DEF very insistent 'Some salesman, a very insistent one.'

Both answers in (1) disallow a continuation that identifies a salesman, such as namely the salesman that stopped by yesterday, which would contradict the ignorance/indifference signaled by the EI. ${ }^{2}$

The properties of vreun and un oarecare are to a large extent shared by EIs attested in other Romance languages, which have received an increasing amount of attention in the last decade: ${ }^{3}$ vreun is in many respects similar to quelque (French),

\footnotetext{
* I would like to thank the editors and two anonymous reviewers for valuable ${ }^{1}$ There is an unfortunate variety of terminology in the field of 'special' indefinites, which includes terms such as modal indefinites, dependent indefinites, anti-specific indefinites or existential free-choice items, among others. I use the term epistemic indefinite to refer to indefinites that convey ignorance or indifference and are incompatible with namely continuations (at least on some of their readings). I set aside specific or wide-scope indefinites such as a certain $N$, which also convey information about an epistemic agent's information state (see e.g. Kratzer 1998, Farkas 2002b, Jayez and Tovena 2006).

2 The namely test was initially used for free relatives, which also have ignorance or indifference readings, see e.g., Dayal (1997, 2013), von Fintel (2000), Condoravdi (2008), Rawlins (2008). Incompatibility with namely is a property that characterizes other marked indefinites, such as negative polarity or free choice indefinites, e.g. I didn't visit any French city, \#namely Paris or You may visit any French city, \# namely Paris. Although originally discussed in the literature in connection with ignorance effects, it should be noted that namely continuations are compatible with free relatives on their agent indifference reading, e.g. Zack voted for whoever was at the top of the ballot, namely John. This suggests that indefinites and free relatives behave differently in this respect. I am not aware of any explanation of this contrast.

${ }^{3}$ See Haspelmath (1997) for cross-linguistic data and the references in e.g., AlonsoOvalle and Menéndez-Benito (2013) and Chierchia (2013).
} 
algún (Spanish) or un qualche (Italian), whereas un oarecare closely resembles un quelconque (French) or un qualunque (Italian). However, it has been shown that vreun has a more restricted distribution than its Romance counterparts (e.g. Fălăuș 2009 , 2014), raising the question of whether this restriction has any impact on the behavior of un oarecare. Both Romanian EIs have been previously described in the literature (Farkas 2002, 2006; Săvescu-Ciucivara 2007; Fălăuș 2009, 2014), but, to my knowledge, their properties have not been systematically compared. This paper seeks to fill this gap, by clarifying and supplementing the description of the Romanian EIs available in the literature. ${ }^{4}$ The two items will be shown to contrast with respect to most parameters of variation argued to be relevant cross-linguistically, a situation that makes Romanian an interesting case study for the typology of EIs.

The paper is organized as follows: section 2 is devoted to the behavior of vreun and un oarecare in episodic, modal and negative polarity contexts, where the two items are shown to be in complementary distribution. Section 3 deals with a further contrast between vreun and un oarecare, namely the inferences observed in modal contexts. More specifically, un oarecare is shown to convey a strong, free choice inference (total variation), unlike vreun, which blocks the free choice inference (requiring partial variation). Section 4 summarizes the properties of the two EIs and briefly lays out some open empirical issues for further research.

\section{Distributional differences}

The determiner vreun (feminine form vreo) is morphologically made up of the standard indefinite article un (masculine)/o (feminine), combined with the morpheme vre- (from the Latin verb volere 'want') and can occur with singular countable nouns, which it always precedes. ${ }^{5}$

The modifier oarecare (morphologically consisting of the interrogative particle oare and the wh-word care 'which') occurs in a wider variety of constructions, illustrated in (2)-(3):
a. Am ridicat receptorul cu o oarecare teamă.
have.1SG picked up phone.DEF with a OARECARE fear
'I picked up the phone with a certain fear.'
b. Are oarecare talent(e) literar(e)

\footnotetext{
${ }^{4}$ The data reported here are based on the research conducted for Fălăuș (2009), which focused on vreun. The examples used in the present paper were tested with an average of twenty native speakers of Romanian, who were asked for judgments on both vreun and oarecare, in informal surveys carried out during individual elicitation sessions.

${ }^{5}$ There is also a partitive version of vreun, which involves the strong form of the indefinite article (which contains the definite article), i.e., vreunul din copii 'one of the children'/vreuna din fete 'one of the girls'. The partitive forms can also be found in the plural - vreunii (masc. pl.)/vreunele (fem. pl.). Both Farkas (2002a) and Fălăuș (2014) note that partitive vreun has a wider distribution than its non-partitive version, but I am not aware of any precise generalizations in this respect.
} 
have.3SG OARECARE talent.PL literary.PL

'(S)he has literary talent(s).'
a. Alege o carte oarecare!
Pick.2SG a card OARECARE
'Pick a card, any card!'
b. Fie A și B două mulțimi oarecare.
Be.3SG A and B two sets OARECARE
'Let A and B be any two sets.'

These examples show that oarecare can appear both in pre- and post-nominal position. The prenominal form is frequently used with non-countable abstract nouns, which can be preceded by the indefinite article (2a), but also occurs with plural forms (2b). This paper focuses on the distribution and interpretation of post-nominal oarecare, which combines with countable nouns and modifies an NP headed by the simple indefinite (3a) or the plural numeral (3b).

With these preliminary remarks in place, let us examine the distribution of the two EIs. I start by considering the contexts where there is a clear distributional difference between vreun and un oarecare (episodic), and follow by discussing the contexts where both items can occur, with important meaning differences (downward entailing contexts, modals and imperatives).

\subsection{Episodic contexts}

Many EIs have been shown to be grammatical in episodic contexts such as (4), where the use of the Spanish determiner algún signals speaker's ignorance with respect to the identity of the student Maria married (e.g. Alonso-Ovalle and Menéndez-Benito 2010):

$$
\begin{aligned}
& \text { María se casó con algún estudiante. } \\
& \text { Maria REFL married with ALGUN student } \\
& \text { 'Maria married some student or other' }
\end{aligned}
$$

The determiner vreun is ruled out from such contexts, even in situations where it is clear that the speaker cannot identify the referent of the vreun-DP:

$$
\begin{aligned}
& \text { *Maria s-a căsătorit cu vreun student (, nu știu } \\
& \text { Maria REFL-have.3SG married with VREUN student NEG know.1SG } \\
& \text { cu cine) } \\
& \text { with who }
\end{aligned}
$$

In contrast to this, un oarecare can be felicitously used in episodic sentences, as illustrated in (6) below: 
Maria REFL-have.3SG registered to a course OARECARE

a. There is a certain course for which Maria registered, the speaker doesn't know or care which course it was.

b. Maria registered for a course she picked randomly.

c. Maria registered for a course, and the speaker finds the course ordinary, unremarkable.

As indicated by the paraphrases above, the use of un oarecare can convey speaker's ignorance or indifference concerning the course for which Maria registered (6a), agent's (i.e. Maria's) indifference with respect to the choice of the course (6b), or speaker's attitude towards the course taken by Maria (6c). The first reading is compatible with Maria having chosen the course carefully, and as such could be followed by something like the most interesting course she found, but I don't remember/care which one that was. This would be impossible on the reading in (6b), which indicates that Maria registered for a course she picked randomly. ${ }^{6}$

Unlike (6a-b), the last reading would allow a continuation like namely the research methodology course, in a context where the speaker belittles the research methodology course. ${ }^{7}$ Moreover, the 'unremarkable' (sometimes derogatory) reading also surfaces when oarecare modifies definite or demonstrative DPs, as in (7) below:

Iar s-a întâlnit cu băiatul acela oarecare, Ion. again REFL-has met with boy.DEF that OARECARE Ion

'She met once again that ordinary boy, Ion.'

The modification of definite noun phrases, together with the acceptability of the namely continuation, sets apart the 'unremarkable' reading of un oarecare from its use as an EI, indicating that perhaps it should receive a different treatment. ${ }^{8}$ In the

\footnotetext{
${ }^{6}$ Some speakers find the reading in (6a) marginal: in the absence of any overt modal, they only accept the agent indifference and the 'unremarkable' reading.

${ }^{7}$ Spanish un cualquiera only has readings (6b-c) and seems compatible with the speaker being able to identify the referent on both these readings, as illustrated in the following example, kindly provided by Luis Alonso-Ovalle and Paula MenéndezBenito (p.c.):

(i) Juan cogió un libro cualquiera - el libro resultó ser Cien años de soledad 'Juan picked a book CUALQUIERA - the book turned out to be One hundred years of solitude.'

The namely continuation (en concreto) is rejected by the Spanish speakers I consulted, but the one in (i) above, which refers to later identification, is perfectly acceptable.

${ }^{8}$ One can also find the 'unremarkable' usage of oarecare with vreun-DPs:

(i) Dacă prindea vreun ins oarecare, fie el și analfabet,...

if caught VREUN guy OARECARE be he even illiterate

'If he caught some ordinary guy, even an illiterate...'

Although still possible in written texts, speakers find this usage rather marginal.
} 
following, I will abstract away from this reading, noting that insofar as I can tell, it is always available.

\subsection{Downward entailing contexts}

The two Romanian EIs differ with respect to their use in negative polarity, i.e. downward entailing contexts: ${ }^{9}$ whereas vreun is used in all negative polarity contexts, un oarecare is either disallowed or acquires a special interpretation. Let us take a closer look at the facts.

As shown in Farkas (2002) and Fălăuș (2009), the determiner vreun clearly does the work of a weak negative polarity item (NPI) ${ }^{10}$ in Romanian, and is used in all contexts where NPI any or ever would be used in English, such as questions and the scope of downward entailing operators like few:
a. Ai elaborat vreun protocol experimental?
have.2SG elaborated VREUN protocol experimental
'Did you design any experimental protocol?'
b. Puţini studenţi au ales vreun curs dintr-un alt department.
Few students have.3PL chosen VREUN course from another department
'Few students have taken any class in another department.'

Like NPIs, vreun needs to occur in the immediate scope of its licensor, a restriction that explains its ungrammaticality in subject position in (9b) or the unacceptability of (9c), where conjunction intervenes between doubt and vreun:
a. Mă îndoiesc că Paul a
obţinut vreun rezultat interesant. REFL doubt.1SG that Paul have.3SG obtained VREUN result interesting 'I doubt that Paul has obtained any interesting result.'
b. *Vreun student se îndoiește că a obţinut rezultate interesante. VREUN student REFL doubts that have.3SG obtained results interesting

\footnotetext{
${ }^{9}$ There are well-known issues arising with respect to the generalization that weak NPIs are licensed in downward entailing contexts, which are not directly relevant to our discussion (see e.g. von Fintel 1999, Gajewski 2008). The only relevant point is the similarity between the distribution of vreun and that of other NPIs.

${ }^{10}$ As shown in section 2.3, vreun can also occur in non-downward entailing contexts. One might therefore object to the term NPI being used in connection with vreun. Similar objections apply to all NPIs that double as FCIs, such as English any. Nothing hinges on this terminological point. I maintain this label simply as a reminder that the behavior of vreun in downward entailing contexts matches that of weak NPIs, e.g. ever. It differs in this respect from other EIs, e.g. Italian un qualche (which is ruled out in negative polarity contexts, see Aloni and Port 2010, Chierchia 2013). Regardless of the terms we employ, I take the (non-)occurrence in downward entailing contexts (and the corresponding interpretation) to be an important parameter of variation among EIs.
} 
'Any student doubts that he has obtained interesting results. 11

c. *Mă îndoiesc că Paul a obţinut date noi și vreun rezultat

REFL doubt.1SG that Paul have.3SG obtained data new and VREUN result interesant.

interesting

'I doubt that Paul has obtained new data and any interesting result.'

The only downward entailing context in which the use of vreun differs from other NPIs is the scope of clausemate sentential negation, where Romanian usually resorts to the negative concord determiner niciun: ${ }^{12}$
a. $\mathrm{Nu}$ cunosc *vreun / $\checkmark$ niciun candidat.
NEG know.1SG VREUN no candidate
'I don't know any candidate.'
b. $\mathrm{Nu}$ cred că Maria cunoaște $\checkmark$ vreun /*niciun candidat
NEG think.1SG that Maria knows VREUN no candidate
'I don't think Maria knows any candidate.'

The similarity between NPIs and vreun noted so far thus seems to break in negative sentences. However, there are both Romanian and cross-linguistic facts indicating this would be a hasty conclusion.

First, a closer look at the data reveals that vreun is not entirely ruled out under local negation. The following examples illustrate this:
a. Nimeni nu a avut vreo informaţie despre crimă.
Nobody NEG have.3SG had VREUN information about murder
'Nobody had any information on the murder.'
b. $\mathrm{Nu}$ am auzit de vreun tratament naturist pentru otită.
NEG have.1SG heard of VREUN treatment natural for otitis
'I haven't heard of any natural treatment (at all) for otitis.'

The most frequent use of vreun with clausemate negation is attested in sentences that already contain a negative concord item preceding vreun, e.g. nimeni 'nobody' in (11a). However, vreun can occur in negative sentences even in the absence of a negative concord item, as in (11b). There are no clear generalizations on the conditions governing the choice between vreun and niciun, but in contexts where they are both possible, such as (11b) above, vreun has been argued to make a less categorical statement. More precisely, "vreun is natural in the presence of a clause-

\footnotetext{
${ }^{11}$ The English paraphrase is acceptable if any acquires a free choice, universal reading (which is impossible for vreun).

${ }^{12}$ Romanian is a strict negative concord language: negative concord items like niciun are only licensed in the presence of clausemate sentential negation and the operator without.
} 
mate negation in examples [...] where it is less likely that the truth of the statement can be checked by verifying all relevant values"(Farkas 2002:138), e.g. all possible treatments in (11b). These examples clearly indicate that vreun can be licensed in the local scope of negation, although its use is more marked and less frequent than what we find for NPIs in other languages.

Second, the more intricate interaction with sentential negation seems to be a recurrent fact cross-linguistically. For example, Kratzer and Shimoyama (2002: 24) show that the German EI irgendein is entirely acceptable in the scope of negative quantifiers like niemand 'nobody' or nie 'never' (12a), and more generally in downward entailing contexts, but not with the negative marker nicht (12b):

$$
\begin{aligned}
& \text { a. Niemand musste irgendjemand einladen. } \\
& \text { Nobody had to IRGEND-ONE invite } \\
& \text { 'Nobody had to invite anybody'. } \\
& \text { b. * Ich hab' nicht irgendwas gelesen. } \\
& \text { I have not IRGEND-WHAT read } \\
& \text { Intended reading: 'I didn't read anything.' }
\end{aligned}
$$

Chierchia (2013) reports a similar pattern for Italian un qualunque NP, which also displays resistance to clausemate negation, while acting as an NPI in all other respects.

These facts indicate that the interaction of EIs with sentential negation can be more complex than in the case of NPIs like any. This restriction is commonly understood as the result of a blocking effect induced by negative concord items. Our present goal is not to explain why and how these effects come about. The main point being made here is that sentential negation should not be taken as the most reliable indicator in assessing whether an EI has an NPI use or not. As far as Romanian is concerned, I take it to be non-controversial that in downward entailing contexts, vreun has the interpretation and the distribution of an NPI.

Things are different with (unfocused) un oarecare, which is infelicitous in typical negative polarity contexts, as attested by the following examples:

a. Puţini studenţi au ales un curs oarecare dintr-un alt Few students have.3PL chosen a course OARECARE from a other department. department

(i) \# Few students have taken any class in another department.

(ii) $\checkmark$ Few students have taken just any course in another department (most took a 5-credit course).

b. Nimeni nu a citit un articol oarecare despre crimă. Nobody NEG have.3SG read an article OARECARE about murder (i) \# Nobody read any article on the murder.

(ii) $\checkmark$ Nobody read just any article on the murder (everyone read the most recent one). 
Un oarecare cannot acquire a narrow scope, NPI-reading in (13). ${ }^{13}$ These sentences become acceptable only if un oarecare is focused, and receives a 'not just any' interpretation, paraphrased in (ii). On this construal, (13a) negates the 'agent indifference' component of un oarecare, yielding an interpretation according to which students carefully picked a course in another department, as indicated by the possible continuation most took a 5-credit course. In the absence of focus or a context strongly favoring the 'not just any' reading, the sentences in (13) are ruled out.

The only negative polarity contexts where un oarecare can have a narrow scope reading are if-antecedents and the restrictor of universal quantifiers, as in (14): ${ }^{14}$

(14) Dacă găseşti vreun articol/ un articol oarecare pe tema asta, trimite-mi-1. if find.2SG VREUN article an article OARECARE on topic this send-me-it 'If you find any paper on this topic, send it to me.'

Both vreun and (unfocused) un oarecare are interpreted in the scope of the ifoperator, without any noticeable meaning difference. It should be noted, however, that the use of vreun constitutes the preferred - and more frequent - option.

Taking stock, the two EIs behave differently in DE contexts - vreun is frequently used and is interpreted as a plain existential, unlike un oarecare, which is much less frequent and only becomes acceptable under a 'not just any' reading, brought about by focus.

\subsection{Modal contexts}

In the contexts discussed so far, the two Romanian EIs are mainly in complementary distribution: vreun is ruled out in episodic contexts, but perfectly acceptable in negative polarity environments, whereas (unfocused) un oarecare shows the opposite pattern (with the notable exception of examples such as (14)). We now turn to modal

${ }^{13}$ Both Săvescu-Ciucivara (2007) and Fălăuș (2009) claim that un oarecare is acceptable in most negative polarity contexts, with the notable exception of local negation and without. Their examples, however, involve a confounding factor, namely a modal or a verb in the present tense (that can be interpreted as a modal), as confirmed by the following example (Săvescu-Ciucivara 2007:14), whose paraphrase contains the modal operator can:

(i) Puţini copii rezolvă o problemă oarecare din manual.

Few kids solve a problem OARECARE from textbook

'Few kids can solve at least one problem from the textbook'.

This problem is avoided in (13), where the use of episodic sentences makes the modal interpretation unavailable. Once we control for this factor, un oarecare cannot take scope below a downward entailing operator like few or nobody, unlike vreun (and NPIs).

${ }^{14}$ Chierchia (2013) notes that the ability to occur in if-antecedents and the restrictor of universal quantifiers seems to characterize all EIs cross-linguistically, regardless of whether they have NPI-uses. See also Chierchia and Liao (this volume). 
contexts, where both items are acceptable, but with important meaning differences. I begin by describing their interaction with modal auxiliaries, and follow by considering their distribution in imperatives.

Like other marked indefinites, e.g. free choice indefinites such as any, EIs are grammatical in the presence of a modal operator. The following examples show that both vreun and un oarecare can co-occur with modals:

a. (Conform contractului,) Maria trebuie/poate să lucreze According contract-the.DAT Maria must may SUBJ work.3sG $\mathrm{cu}$ un coleg oarecare.

with a colleague OARECARE

'(According to her contract,) Maria must/may work with a colleague.'

b. (Din câte știu,) Maria trebuie/poate să fie cu vreun

From what know.1SG Maria must may SUBJ be.3SG with VREUN coleg.

colleague

'(As far as I know,) Maria must/may be with a colleague.'

However, their use in modal contexts is not restriction-free. One key factor for their acceptability is the modal base determining the interpretation of the modal auxiliary. More specifically, vreun is only acceptable if the modal is construed as epistemic, as extensively discussed in Fălăuș $(2009,2014)$, where this restriction is dubbed 'the epistemic constraint'. Whenever vreun can be felicitously used in a modal context, it signals speaker's ignorance or indifference with respect to the referent of the nominal phrase. Accordingly, the only possible interpretation of (15b) is that as far as the speaker knows, Maria must/may be with some colleague and the speaker doesn't know (or care) who that is. If we try to force a non-epistemic reading, e.g. Maria is obliged/allowed to be with some colleague, the sentence would be ruled out. The ungrammaticality of the following examples, where the modal acquires a deontic (16a) or a teleological reading (16b), provides further evidence for this restriction:

$$
\begin{aligned}
& \text { a. *Trebuie/*Pot să pregătesc vreun curs până mâine } \\
& \text { must may SUBJ prepare.1SG VREUN course by tomorrow } \\
& \text { 'I must/may prepare a course by tomorrow.' } \\
& \text { b. *Ca să ajung în centru, trebuie/pot să iau vreun autobuz. } \\
& \text { that SUBJ get.1SG in center must /may sUBJ take.1SG VREUN bus } \\
& \text { 'In order to get downtown, I must/may take a bus.' }
\end{aligned}
$$

The restriction to epistemic contexts displayed by vreun indicates that certain EIs are sensitive to the interpretation of the modal. In contrast to vreun, whose interaction with modals is by now quite well studied, the data concerning the modal bases admitted by un oarecare are less clear. All examples attested in previous studies involve non-epistemic modals, as in (15a) above. Likewise, un oarecare could felicitously occur in the sentences in (16). As pointed out in Săvescu-Ciucivara 
(2007), the use of un oarecare in modal contexts typically brings about the same readings discussed in episodic contexts (see (6) above). With the necessity modal in (15a) for example, we obtain the speaker ignorance/indifference reading in (17a) and the reading in (17b), according to which Maria has to work with a colleague and it could be any colleague. This latter reading surfaces in a context where, for instance, Maria is known to always work on her own, which made her boss worry about her teamwork skills. To dispel such concerns, all Maria has to do is to work with a colleague and she can freely choose among her colleagues:

(17) a. There is a certain colleague Maria has to work with, the speaker doesn't know or care who it was.

b. Maria has to work with a colleague, and she can choose any colleague.

c. Maria has to randomly pick the colleague she works with.

In addition, un oarecare can also acquire the reading in (17c), which states that Maria has the obligation to randomly choose the colleague she works with. ${ }^{15}$ This interpretation is not very salient, but can surface in the right scenario. Imagine for example that Maria is always very picky when it comes to collaborating with colleagues. To change this image, she must stop being so demanding and randomly pick a colleague.

The question is what happens when the modal is interpreted with respect to an epistemic modal base. In order to answer this question, I've conducted an informal study in which twenty native speakers participated in two different tasks: (i) a task in which they were presented with modal statements (modal auxiliaries and imperatives ${ }^{16}$ ) with the two EIs and had to supply an appropriate context of use and (ii) a task in which they were presented with a context of use and had to choose the appropriate EI. ${ }^{17}$

In the first task, the speakers were presented with modal sentences with both vreun and un oarecare, and were asked to describe a context where they would use those examples. Crucially, there was nothing in the sentence (e.g. type of predicate, subject or tense information) that favored an epistemic or a non-epistemic construal of the modal. ${ }^{18}$ Speakers systematically provided non-epistemic contexts with un

\footnotetext{
${ }^{15} \mathrm{I}$ 'm grateful to the editors for drawing my attention to this reading.

${ }^{16} \mathrm{I}$ 'm assuming imperatives are very similar to modals, following e.g. Kaufmann (2012). For different views and detailed analyses of imperatives, see e.g. Portner (2007, 2009), Condoravdi and Lauer (2012).

${ }^{17}$ To avoid any effect of intonation, the sentences were presented in a written form.

${ }^{18}$ The interpretation of modals is determined by a large variety of factors (e.g. subject or tense), which need to be controlled for in order to construct fully ambiguous examples. There are many intricacies that further complicate this task. For example, the word poate is ambiguous: it can mean 'perhaps, maybe', in which case it is followed by an inflected verbal form (indicative present tense, $3^{\text {rd }}$ person in (19)); but it can also be the inflected, $3^{\text {rd }}$ person form of the possibility modal a putea 'may, can', which is followed by an infinitive or subjunctive (15). Since the indicative
} 
oarecare (18a-19a), and, as expected, only epistemic ones with vreun (18b-19b). The sentences and the associated contexts looked as in (18)-(19) below:

Trebuie să găsesc un zbor oarecarel vreun zbor spre Roma. must SUBJ find.1sG a flight OARECARE VREUN flight to Roma 'I must find a flight to Rome/There must be some flight to Rome that I can find.'

a. I have just missed my flight to Rome and I need to get there by tomorrow. I would be happy with any flight (even if I am generally very picky with respect to air companies).

b. I am thinking to go to Rome during the weekend, but haven't bought tickets in advance. However, I know that my hometown has good air connections with Italy, so I am pretty sure there will be no problems finding a flight.

(19) Poate alege un curs oarecare / vreun curs de lingvistică. may.3SG choose a course OARECARE VREUN course of linguistics 'He may/might choose a course in linguistics.'

a. Marc needs to register for a linguistics course to get his degree in philology, and he has complete freedom with respect to the course he chooses.

b. Marc is a very good student in philosophy and has to register for some class in another department. He has expressed interest in linguistics on previous occasions, so perhaps he will choose a linguistics course.

In the other task, involving the same set of speakers, but performed in a different elicitation session, speakers were given the context of utterance (epistemic or non-epistemic, along the lines of the contexts provided above) and (ambiguous) modal sentences without the EI. ${ }^{19}$ They were asked to insert either vreun or un oarecare. Once again, there was a systematic correlation between epistemic contexts and vreun on the one hand, and non-epistemic contexts and un oarecare on the other. When asked if un oarecare would also have been possible, albeit dispreferred, in epistemic set-ups, the answer was generally negative, suggesting that un oarecare does not (easily) admit an epistemic modal base. ${ }^{20}$ However, at least for some speakers, this conclusion turns out to be too strong. ${ }^{21}$ One can find speakers that accept sentences like the following:

present for the $3^{\text {rd }}$ person and the infinitive form of alege 'choose' are homonymous, (19) is ambiguous between an epistemic (where poate is interpreted as perhaps) and a non-epistemic reading (where poate means (s)he may/can).

${ }^{19}$ The sentences were different from the ones used in the first task, but once again, they were compatible with both epistemic and non-epistemic construals of the modal.

${ }^{20}$ Some speakers tried to force the 'unremarkable', depreciative reading of oarecare (which is always available), but this triggered a change of the context as well.

${ }^{21}$ More specifically, five of the twenty informants I worked with in these two tasks occasionally accepted un oarecare with epistemic modal bases. The evidence gathered doesn't support the conclusion that un oarecare can freely occur with 
Trebuie să fi intrat într-un magazin oarecare și să-și fi must SUBJ be entered in a store OARECARE and SUBJ-CL be cheltuit toţi banii.

spent all money

'She must have entered some store and spent all her money.'

(21) Trebuie să fi ales o rochie oarecare.

must SUBJ be chosen a dress OARECARE

'She must have chosen some dress.'

The modal is obligatorily epistemic in these sentences, yet un oarecare is possible. The reported reading is the 'agent indifference' reading, according to which someone randomly picked a store or a dress. However, the speaker indifference or ignorance reading is not entirely impossible. Some of the speakers who accept un oarecare with epistemic modals find (21) acceptable in both of the following scenarios:

a. SCENARIO 1: Lisa is very excited about her wedding. Yesterday she had an appointment to choose her wedding dress. Unlike her, I am not a wedding enthusiast, so I don't care too much about the details of her wedding preparations.

b. SCENARIO 2: Lisa is getting married, but she doesn't care much about the details of her wedding preparations. Knowing her, I am sure she picked randomly her wedding dress.

The first scenario favors the interpretation whereby for all the speaker knows, Lisa carefully chose her dress, but speaker doesn't know or care which dress she picked (speaker ignorance or indifference). In the second scenario, the most salient reading is the agent indifference reading, i.e. Lisa didn't care much about the choice of her wedding dress. Most speakers who accept un oarecare in epistemic set-ups prefer scenario 2, but some speakers accept scenario 1 as well.

Taking stock, the distribution of EIs in modal contexts is sensitive to the modal base. The determiner vreun requires an epistemic construal of the modal, as attested by its exclusion with root modals (cf. (16) above). In contrast to this, un oarecare freely admits any non-epistemic interpretation of the modal (as in (15a)), but seems ruled out (or only marginally possible) with epistemic modals. Once we take

epistemic modal bases. The (five) speakers never volunteered un oarecare with epistemic modals, they only accepted it when asked follow-up questions on whether un oarecare could have been used instead of vreun. Moreover, they didn't accept it systematically, i.e. they sometimes accepted un oarecare in a context that favored, say, the agent indifference reading (along the lines of Scenario 2 in (22)), but didn't accept it in a similar scenario. It is not clear at this point what are the factors that determine the acceptability of these examples for these speakers, so I must leave this as an issue for future research. 
into account the modal base, the two Romanian EIs appear to have a complementary distribution, just like in episodic and downward entailing contexts.

This rather uniform picture breaks down in imperatives, where a puzzling pattern can be observed, a fact noted in Fălăuș (2011). ${ }^{22}$ Consider the following examples:

a. Înscrie-te la $\checkmark$ un curs oarecare/ $\checkmark$ vreun curs la noi în departament! register. IMP.2SG to a course OARECARE VREUN course at us in department 'Register for a course in our department!'

b. (Pentru a începe jocul,) Alege $\checkmark$ o carte oarecare /\#vreo carte! for to start game.DEF choose.IMP.2SG a card OARECARE VREUN card '(To start the game), pick a card!'

c. (Pentru a afla dacă ai drept de vot,) for to find out if have.2SG right of vote Întreabă \#un angajat oarecare $/ \checkmark$ vreun angajat de la Primărie. ask.IMP.2SG an employee OARECARE VREUN employee from City Hall '(To find out if you have the right to vote,) ask an employee from the City Hall!'

The sentences in (23) show that both un oarecare and vreun can sometimes be used in imperatives. Knowing the close similarity between modals and imperatives (see e.g. Kaufmann 2012), the occurrence of the two EIs in imperatives is expected. The challenge consists in identifying the factor(s) determining their acceptability. What are the properties of the imperatives that allow both vreun and un oarecare in (23a), as opposed to those where only one of the two EIs is possible (23b-c)? Furthermore, how does the pattern in (23) correlate with the split between epistemic and nonepistemic modality that governs the distribution of vreun and un oarecare in modal contexts? To answer these questions, we need to examine in more detail the interpretation of the two EIs. The facts discussed in the next section show that vreun and un oarecare sustain different modal inferences, a distinction that in Fălăuş (2011, 2014 ) is argued to be responsible for their behavior in modal contexts and imperatives.

\section{Differences in interpretation: modal inference}

In the previous section, we discussed variation in the distribution of un oarecare and vreun. As far as their interpretation is concerned, so far we have focused on their

\footnotetext{
${ }^{22}$ The distribution of the two EIs in imperatives is not very easy to determine: some speakers (seven out of the twenty speakers I consulted) find EIs marginal in imperatives to begin with and systematically use the simple indefinite or the free choice determiner orice 'any'. Speakers' intuitions are much more solid with modal auxiliaries, but for the speakers who accept the use of EIs in imperatives, it is fairly clear that their distribution is sensitive to the distinction between partial and total variation contexts.
} 
compatibility with different modal bases, and with speaker ignorance or agent indifference readings. We now turn to a parameter of variation that has received a lot of attention in the recent literature on EIs (e.g. Aloni and Port 2010; Alonso-Ovalle and Menéndez-Benito 2008, 2010, 2013; Chierchia 2013; Fălăuş 2009, 2010, 2014; Jayez and Tovena 2007), namely the modal inference they trigger.

As indicated by the unacceptability of the namely continuation (cf. the examples in (1)), EIs require a certain degree of ignorance with respect to the referent of the indefinite, i.e. there has to be more than one possible value in the relevant domain. They differ however with respect to the extent of variation ('freedom of choice') imposed on the domain of quantification, which can be total or partial (as noted in Jayez and Tovena 2007, Alonso-Ovalle and Menéndez-Benito 2008 and extensively discussed in subsequent work on EIs):
a. $\forall x \gg \phi$
TOTAL VARIATION
(aka Free Choice)
b. $\neg \exists x \square \phi$
PARTIAL VARIATION
(aka Modal Variation)

On the one hand, certain epistemic indefinites, e.g. Italian un qualsiasi or French un quelconque, sustain TOTAL variation, requiring that all relevant alternatives in the domain of quantification qualify as equally possible options (as represented in the formula in (24a)). On the other hand, other EIs, e.g. Spanish algún or Italian un qualche, trigger a weaker inference (24b), namely PARTIAL variation: some, but not necessarily all alternatives in the relevant domain are epistemic possibilities. Crucially, this weaker inference is compatible with the exclusion of some of the possible options. An interesting case in this connection is German irgendein (Kratzer and Shimoyama 2002), whose modal inference has been argued to vary with the context of occurrence (Aloni and Port 2010, Lauer 2010). More precisely, the following examples, taken from Aloni and Port (2010), show that irgendein triggers total variation in deontic contexts $(25 \mathrm{a})$, and partial variation in epistemic contexts (25b):

(25) a. Maria muss irgendeinen Arzt heiraten.

German

Mary must IRGENDEIN doctor marry

'Mary must marry a doctor, any doctor is a permissible option.'

b. Maria muss irgendeinen Arzt geheiratet haben.

Maria must IRGENDEIN doctor married have

'Maria must have married some doctor, I don't know who.'

In the following, we examine the degree of ignorance required by un oarecare and vreun. I show that un oarecare always associates with total variation, and as such is ruled out in partial variation set-ups. Vreun displays the exactly opposite pattern - it is only compatible with partial variation scenarios.

\section{1 'Un oarecare' and Total Variation}


The examples we have seen so far show that un oarecare sustains a strong, total variation inference. The sentence in (15) above, repeated in (26), makes a modal claim - Maria must/may work with a colleague - and indicates that any one of Maria's colleagues is a permissible option:
Maria trebuie/poate să
lucreze $\mathrm{cu}$ un coleg
oarecare
Maria must can SUBJ work.3SG with a colleague OARECARE
'Maria must/may work with a colleague (and it could be any colleague).'

The question is what happens in partial variation contexts. A useful set-up to answer this question is the hide-and-seek scenario in (27), due to Alonso-Ovalle and Menéndez-Benito (2010):

THE HIDE-AND-SEEK SCENARIO

Maria, Juan, and Pedro are playing hide-and-seek in their country house. Juan is hiding. Pedro believes that Juan is inside the house, and is sure that Juan is not in the bathroom or in the kitchen. As far as he knows, Juan could be in any of the other rooms in the house.

The context makes it clear that not all rooms are epistemic possibilities, i.e. not the bathroom or the kitchen. None of the following examples could be felicitously uttered by Pedro in this scenario: ${ }^{23}$

\#Juan s-a ascuns într-o cameră oarecare din casă.
Juan REFL-have.3SG hidden in a room OARECARE in house
'Juan has hidden in a room of the house.'
\#Trebuie să-l căutăm pe Juan într-o cameră oarecare din casă.
must SUBJ-CL search.1PL ACC Juan in a room OARECARE in house
'We must look for Juan in a room of the house.'
\#Putem să-1 găsim pe Juan într-o cameră oarecare din casă.
can.1PL SUBJ-CL find.1PL ACC Juan in a room OARECARE in house
'We can find Juan in a room of the house.'

The infelicity of (28)-(30) indicates that un oarecare is ruled out in a partial variation scenario, regardless of whether it is used in an episodic or a modal context (deontic in (29) or ability (30)). Recall that un oarecare is normally acceptable with nonepistemic modals (see (15)), yet, here it is not. Of course, such sentences could be used by, say, Maria if she didn't exclude any room in the house. On the basis of these examples, I conclude that un oarecare requires total variation.

\footnotetext{
${ }^{23}$ Unless un oarecare acquires the 'unremarkable' reading, which is always possible, but which does not require variation.
} 


\section{2 'Vreun' and Partial Variation}

Let us now turn to vreun. In contrast with un oarecare, vreun is perfectly felicitous in the partial variation scenario in (27), where Pedro could felicitously utter the following sentences:
a. Juan trebuie să fie în vreo cameră din casă.
Juan must SUBJ be.3SG in VREUN room in house
'Juan must be in a room of the house.'
b. Juan poate să fie în vreo cameră din casă.
Juan may SUBJ be.3SG in VREUN room in house
'Juan may be in a room of the house.'

As shown in section 2, vreun is ruled out in episodic and non-epistemic modal sentences (see examples in (5) and (16) above), so we can only examine its behavior in epistemic contexts. The sentences in (31) indicate that vreun is compatible with partial variation set-ups, unlike un oarecare.

This behavior immediately raises the question of what happens with vreun in total variation scenarios. Fălăuş (2014) argues that vreun is incompatible with total variation. The sentences in (31), for example, would be deviant in a context that makes it clear that any room of the house is a possibility. The epistemic context in (32), which enforces total variation, further illustrates this point: ${ }^{24}$

(32) The shell game requires three shells or boxes and a small ball. The ball is placed under one of the boxes and then the operator quickly shuffles the boxes around. In order to win, the player has to correctly identify the box containing the ball.
a. \#Mingea trebuie să fie în vreo cutie (şi poate fi oricare din cele ball-the must SUBJ be.3SG in VREUN box and could be any of the trei cutii).
three boxes
'The ball must be in a box (and it could be any of the three boxes).'
b. \#Mingea poate să fie în vreo cutie (şi poate fi oricare din cele ball-the may SUBJ be.3SG in VREUN box and could be any of the

\footnotetext{
${ }^{24}$ A possible issue arising in contexts that seek to enforce total variation is the use of partitive indefinites (plain or epistemic). Since the set of possible values is very clear in the context, the default option used by speakers is a partitive indefinite (one of the boxes). The continuation in (32), and it could be any of the three boxes, rendered the use of a plain indefinite ( $a$ box) felicitous. In contrast to this, vreun is deviant, a fact that I take to indicate incompatibility with total variation. In this respect, vreun differs from Spanish algún, which does not require total variation, but is compatible with it (see Alonso-Ovalle and Menéndez-Benito 2013 for discussion of this issue). An important related matter, which I must leave for future work, is the behavior of partitive vreun in this context.
} 
trei cutii).

three boxes

'The ball may be in a box (and it could be any of the three boxes).'

The scenario in (32) makes it clear that the ball could be in any of the three boxes under consideration, although the speaker does not know which is the right one. However, despite the fact that the speaker cannot identify the box satisfying the modal claim, vreun cannot be used. This shows that vreun is incompatible with total variation, in contrast to what we observed for un oarecare, which requires it. ${ }^{25}$

With this in mind, we can now return to the distribution of the two EIs in imperatives. Recall the pattern observed in (23) above, repeated below:

a. Înscrie-te la $\checkmark$ un curs oarecare/ $\checkmark$ vreun curs la noi în departament! register. IMP.2SG to a course OARECARE VREUN course at us in department 'Register for a course in our department!'

b. (Pentru a începe jocul,) Alege $\quad \checkmark$ o carte oarecare/\#vreo carte! for to start game.DEF choose.IMP.2SG a card OARECARE VREUN card '(To start the game), pick a card!'

c. (Pentru a afla dacă ai drept de vot,) for to find out if have.2SG right of vote Întreabă \#un angajat oarecare $/ \checkmark$ vreun angajat de la Primărie. ask.IMP.2SG an employee OARECARE VREUN employee from City Hall '(To find out if you have the right to vote,) ask an employee from the City Hall!'

While I do not have a detailed description of what determines these judgments, let me just mention a correlation that emerged during my survey and that I view as an interesting point of departure for a line of analysis. More precisely, there seems to be a correlation with the total/partial variation distinction between un oarecare and vreun discussed above (see Fălăuș 2011). Recall that in interaction with modal auxiliaries, un oarecare is acceptable in total variation contexts, and vreun in partial variation ones. A similar pattern emerges in imperatives - in the absence of any indication of the contrary, this is exactly how speakers describe the default interpretations and contexts of utterance for the imperatives in (33). For example, (33b) is typically uttered in front of a pack of cards, a context where normally all cards qualify as equally viable options. Consequently, un oarecare can be felicitously used. In contrast to this, the imperative in (33c) is typically construed as a partial variation context - it is easy to assume that not any City Hall employee would be able to

\footnotetext{
${ }^{25}$ Un oarecare is also ruled out in the shell game context, with or without an overt modal. Given that most speakers reject un oarecare in epistemic settings, this is expected. The speakers who accept un oarecare with epistemics reject it in this context, stating that un oarecare would imply that the speaker doesn't care where the ball is, which is ruled out in the given scenario.
} 
provide information on voting rights, e.g. not those working in the financial department. This might explain the acceptability of vreun and the deviance of $u n$ oarecare.$^{26}$ Finally, (33a) can go both ways: it can either be the case that any course in our department would do for the relevant purposes (and un oarecare could be used), or rather that only some courses would satisfy the relevant goals or desires (in which case only vreun would be possible). These preferences correlate with the behavior observed in modal contexts: un oarecare requires total variation, and vreun requires partial variation contexts. Determining what makes an imperative more likely to be associated with a total or a partial variation context is a non-trivial matter, which cannot be properly addressed here. ${ }^{27}$ I hope however that the data reported here can foster research on the behavior of EIs in modal and imperative contexts and further probe the connection with the total/partial variation parameter.

\section{Further issues}

This concludes our overview of the core properties of un oarecare and vreun. Their behavior can be summarized as follows:

(34) Romanian Epistemic Indefinites:

\begin{tabular}{|l|l|l|}
\cline { 2 - 3 } \multicolumn{1}{c|}{} & VREUN & UN OARECARE \\
\hline Episodic contexts & no & yes \\
\hline NPI-readings in negative polarity contexts 29 & yes & no \\
\hline Modal contexts & epistemic & $\begin{array}{l}\text { (mainly) non- } \\
\text { epistemic }\end{array}$ \\
\hline Modal inference & Partial Variation & Total Variation \\
\hline
\end{tabular}

The table in (34) shows that the two Romanian EIs differ both in terms of their distribution and their interpretation. On the one hand, vreun is only compatible with partial variation scenarios, is restricted to epistemic contexts, and admits an NPI use. On the other hand, un oarecare requires total variation, occurs in episodic and (for most speakers) non-epistemic modal contexts, while disallowing an NPI use. To this we can add their readings: whereas un oarecare can have both speaker and agent-

\footnotetext{
${ }^{26}$ If the context makes it clear that all City Hall employees are well informed on voting rights, un oarecare becomes felicitous.

${ }^{27}$ A more general question is what determines the choice of quantificational domains. And moreover, what are the factors that make a context satisfy total or partial variation. In Fălăuş (2014), I address this issue for modal operators. For relevant discussion, see also Aloni (2007), Aloni \& Port (this volume), Chierchia (2013).

${ }^{28}$ This refers to unfocused un oarecare. As mentioned in section 2.2, focus allows un oarecare to occur in DE-contexts, with a 'not just any' reading.

${ }^{29}$ Setting aside if-antecedents and the restrictor of a universal quantifier.
} 
oriented ignorance and indifference readings, insofar as I can tell, vreun is more speaker-oriented. ${ }^{30}$

To complete this picture, let me briefly add further distinctions between vreun and un oarecare, which have received less attention in the literature. As mentioned at the beginning of this paper, the two EIs also differ with respect to their interaction with plurality: oarecare can combine with plural nouns (and cardinals such as two, three, etc., as in (3b) above), unlike (non-partitive) vreun which lacks a plural form and can only combine with singular nouns.

In Fălăuş (2013), I discuss another parameter of variation, namely interaction with focus. The following examples show that un oarecare can be focused in both modal and negative polarity contexts, where it receives a 'not just any reading' (as discussed in connection with (13)): $:^{31}$

(35) Nimeni nu a vizitat un muzeu OARECARE.

Nobody NEG has visited a museum OARECARE

a. *Nobody has visited any museum.

b. $\checkmark$ Nobody has visited just any museum (everyone picked their favorite one).

(36) Maria e foarte inteligentă, poate rezolva $\boldsymbol{o}$ problemă OARECARE din acest

Maria is very intelligent can.3SG solve a problem OARECARE from this

manual în mai puţin de trei minute.

manual in more less of three minutes

'Maria is very smart, she can solve ANY problem from this textbook in less than three minutes.'

In contrast to this, the presence of focus renders vreun deviant, regardless of whether it occurs in a negative polarity or an epistemic modal context:
a. *Nimeni nu are VREUN bilet la concert.
Nobody NEG have.3SG VREUN ticket to concert
'Nobody had any ticket to the concert.'
b. *Se poate ca Maria să meargă la VREUN concert diseară.
SE may that Maria SUBJ go.3SG to VREUN concert tonight
'Maria might go to a concert tonight.'

The fact that vreun cannot be stressed is surprising: all closely related categories simple indefinites, un oarecare or negative concord items - can be (at least contrastively) focused. In Fălăuş (2013), I show that this restriction is shared by other partial variation EIs and attribute their behavior to the interaction between lexically induced and focus alternatives.

\footnotetext{
${ }^{30}$ The compatibility of vreun with agent-oriented readings can only be determined through a detailed investigation of its behavior in attitude contexts, something that goes beyond the scope of the present paper.

${ }^{31}$ I use small caps to indicate focus.
} 
There are other contexts where the two Romanian EIs under consideration can occur, but have been left out of the discussion. For example, Farkas (2002a, 2006) shows that vreun is licensed by the frequentative imperfective in (38):

Din când în când trenul se oprea în vreo haltă și câte from when in when train.DEF REFL stop.IMPF.3SG in VREUN station and DIST un navetist deschidea un ochi.

a commuter opened an eye

'From time to time, the train would stop in some station and a commuter would open an eye.'

The distribution in attitude contexts reveals further interesting properties of vreun, extensively discussed in Fălăuș $(2009,2014)$. For instance, it is ruled out under epistemic factives like know, but acceptable under non-factive doxastics like believe or think (39); furthermore, it is ruled out under want, but acceptable under hope (40):

*Ştiu $\quad / \checkmark$ Cred că am vreun virus în calculator. know.1SG believe.1SG that have.1SG VREUN virus in computer 'I know/ I think I have a virus in my computer.'

*Vreau / $\checkmark$ Sper să găsesc vreun cadou pentru sora mea.
want.1SG hope.1SG SUBJ find.1SG VREUN present for sister.DEF my
'I want/I hope to find a present for my sister.'

The behavior of un oarecare in attitude contexts hasn't yet been investigated. These examples indicate the need to examine the interaction between EIs and tense, aspect, or embedding predicate, something that cannot be done within the limits of this paper. In order to properly describe and capture the use of EIs with attitude predicates, we need to determine (i) their acceptability and (ii) their contribution to the overall meaning of the sentences where they are felicitous. This turns out to be a complex and difficult task. Propositional attitudes in Romanian display intricate, yet poorly understood, properties of their own (see Farkas 1992, Braşoveanu 2006, Brașoveanu and Farkas 2007). As a result, it is often difficult to disentangle the role of the EI from that of the embedding predicate, embedded tense or mood, and identify the factors responsible for the (un)acceptability of a given example. ${ }^{32}$ Future research needs to probe further into these properties and establish how the behavior of the two EIs in attitude contexts fits into the picture described in (34).

I would like to conclude this description by emphasizing a point emerging from all previous studies on Romanian indefinites, namely the importance of approaching them as members of a system. More specifically, there are numerous instances of overlap and competition between the various indefinites attested in a given language, which cannot be understood if the items are studied in isolation. Farkas (2002a, 2006) discusses at length the similarities and differences between

${ }^{32}$ See Fălăuş (2014) for further discussion. 
vreun and the universal free choice determiner orice/oricare 'any'. In section 2.2 above, we have seen that the distribution of vreun in downward entailing contexts closely resembles that of other NPIs, and that its behavior in the scope of clausemate negation is tightly connected to the negative concord item niciun. Similar considerations apply to the relation between vreun and un oarecare, which in turn are closely related to simple indefinites and (universal) free choice items. In view of the pervasive connections between EI and other indefinites, the advantages of a unitary approach become self-evident. In Fălăuş (2014), I adopt the alternative-based framework in Chierchia (2013) and argue that the properties of vreun, and more generally of EIs, are best understood within a unified theory of polarity and free choice phenomena. On this approach, EIs share with other indefinite elements (e.g. NPIs, free choice items, minimizers) the property of being existential elements that activate alternatives. The way these alternatives are factored into meaning and the semantic properties of the operators in the context (e.g. downward entailing and modals) determine their distribution and interpretation. Once we adopt such an account, and carefully motivate it, a rather large set of empirical differences between un oarecare and vreun can be derived from the interaction between their lexical semantics and that of the operators with which they interact. For example, on this proposal, the restriction of vreun to epistemic contexts follows from the lexicalization of a ban on total variation, due to a competition with un oarecare. This constraint, together with independent properties of the embedding modal, is responsible for the more restricted distribution of vreun. The reader is referred to Fălăuş (2014) for details.

Taking stock, the goal of this essentially descriptive paper was to contribute to a better understanding of EIs, by comparing the properties of the Romanian items vreun and un oarecare and briefly laying out the main areas in need of further investigation. Without drawing an exhaustive picture of the behavior of the two items, the facts discussed here offer a better perspective on what needs to be captured by theories of EIs. One of the main conclusions that emerges from the study of Romanian is the fact that EIs behave differently in the scope of epistemic and root modals, a conclusion that has been confirmed for other languages (e.g. Aloni and Port 2010). The discovery of a new dimension of variation - type of modality - and the connection with the total/partial variation distinction illustrated by EIs like German irgendein (see examples in (25) above), shows that EIs represent a fruitful area of investigation, whose study can lead not only to a better understanding of variation among indefinites, but also shed light on the semantics of the contexts where they occur.

Taken together, the data discussed in this paper indicate that un oarecare and vreun differ with respect to a large number of dimensions of variation. To my knowledge, things are not as clear-cut in other languages studied to date, where the equivalents of vreun seem to be compatible with a wider range of contexts and interpretations. For example, Italian un qualche or Spanish algún signal partial variation, but are nevertheless compatible with total variation contexts (for discussion, see e.g. Aloni and Port 2010, Alonso-Ovalle and Menéndez-Benito 2013, Chierchia 
2013). Moreover, the exclusion from episodic and non-epistemic modal environments doesn't seem to characterize any other EI described in the literature. The contrasting picture presented here thus shows that Romanian can provide useful insights into the typology of epistemic indefinites.

\section{References}

Aloni, Maria (2007). Free choice, modals and imperatives. Natural Language Semantics 15:65-94.

Aloni, Maria and Angelika Port (2010). 'Epistemic indefinites crosslinguistically', in Proceedings of NELS 41.

Alonso-Ovalle, Luis and Paula Menéndez-Benito (2008). 'Minimal domain widening', in Proceedings of the 27th West Coast Conference on Formal Linguistics, N. Abner and J. Bishop (eds), pp. 36-44. Somerville, MA: Cascadilla Proceedings Project.

Alonso-Ovalle, Luis and Paula Menéndez-Benito (2010). 'Modal Indefinites'. Natural Language Semantics 18(1): 1-31.

Alonso-Ovalle, Luis and Paula Menéndez-Benito (2013). 'Two views on epistemic indefinites', Language and Linguistics Compass 7/2: 105-122.

Braşoveanu, Adrian (2006). 'Temporal and Propositional De Se: Evidence from Romanian Subjunctive Mood', in Proceedings of Sinn und Bedeutung 10: 55-70.

Braşoveanu, Adrian and Donka Farkas (2007). 'Say Reports, Assertion Events and Meaning Dimensions', in Pitar Moş: A Building with a View. Papers in Honour of Alexandra Cornilescu, G. Alboiu, A. Avram, L. Avram, and D. Isac (eds.), pp. 23-43, Bucharest: Editura Universităţii din Bucureşti.

Chierchia, Gennaro (2006). 'Broaden your Views. Implicatures of Domain Widening and the Spontaneous Logicality of Language', Linguistic Inquiry 37(4): 535-590.

Chierchia, Gennaro (2013). Logic in Grammar: Polarity, Free Choice and Intervention, Oxford University Press.

Condoravdi, Cleo (2008). 'Whatever: Free Choice and Uncertainty'. Paper presented at the Informal Formal Semantics Group, Stanford University.

Condoravdi, Cleo and Sven Lauer (2012). 'Imperatives: Meaning and illocutionary force', in Empirical Issues in Syntax and Semantics 9, Papers from the Colloque de Syntaxe et Sémantique à Paris, C. Piñon (ed.), pp. 37-58.

Dayal, Veneeta. (1997). Free relatives and ever: identity and free choice readings, in Proceedings of SALT VII, A. Lawson (ed.), pp. 99-116. Ithaca, NY: Cornell University.

Dayal, Veneeta. (2013). 'A viability constraint on alternatives for free choice'. In Alternatives in Semantics, A. Fălăuş (ed.), Palgrave Macmillan.

Farkas, Donka (1992). 'On The Semantics of Subjunctive Complements', in Romance Languages and Modern Linguistic Theory, P. Hirschbühler et al. (eds.), pp. 69104. Amsterdam: John Benjamins. 
Farkas, Donka (2002a). 'Extreme Non-Specificity in Romanian', in Romance Languages and Linguistic Theory 2000, C. Beyssade et al. (eds.), pp. 127-153. Amsterdam: John Benjamins.

Farkas, Donka (2002b). 'Varieties of indefinites', in Proceedings from SALT XII, Ithaca, NY: Cornell University, 59-83

Farkas, Donka (2006). 'Free Choice in Romanian', in Drawing the Boundaries of Meaning, Neo-Gricean Studies in Pragmatics and Semantics in Honor of Laurence R. Horn, B. J. Birner and G. Ward (eds.), pp. 71-94. Amsterdam: John Benjamins.

Fălăuş, Anamaria (2009). Polarity items and dependent indefinites in Romanian, $\mathrm{PhD}$ dissertation, University of Nantes.

Fălăuş, Anamaria (2010). 'Alternatives as sources of semantic dependency'. in Proceedings of SALT 20, N. Li and D. Lutz (eds.), pp. 406-427. eLanguage.

Fălăuş, Anamaria (2011). 'On alternatives in imperatives: the case of Romanian vreun', in Proceedings of Sinn und Bedeutung 16:1, A. Aguilar, A.

Chernilovskaya, and R. Nouwen (eds.), pp. 239-252

Fălăuş, Anamaria (2013). 'Broaden your views but try to stay focused: a missing piece in the polarity system', in From Grammar to Meaning: The Spontaneous Logicality of Language, I. Caponigro and C. Cecchetto (eds.), pp. 81-107. Cambridge University Press.

Fălăuş, Anamaria (2014). ‘(Partially) Free Choice of Alternatives.' Linguistics and Philosophy, 37(2):121-173

von Fintel, Kai (1999). 'NPI-Licensing, Strawson-Entailment, and Context Dependency'. Journal of Semantics 16: 97-148.

von Fintel, Kai. (2000). 'Whatever'. In Proceedings from Semantics and Linguistic Theory (SALT 10), B. Jackson and T. Matthews (eds.), pp. 27-39. Ithaca, NY: Cornell University

Gajewski, Jon (2008). 'Licensing Strong NPIs', in University of Pennsylvania Working Papers in Linguistics Volume 14:1, J. Tauberer, A. Eliam, and L. MacKenzie (eds.), pp. 163-176. Philadelphia, PA: UPenn Working Papers. Haspelmath, Martin (1997). Indefinite pronouns. Oxford University Press, Oxford. Jayez, Jacques and Lucia Tovena (2006). 'Epistemic determiners'. Journal of Semantics, 23:3, 217-250.

Jayez, Jacques and Lucia Tovena (2007). 'Evidentiality and determination', in Proceedings of Sinn und Bedeutung 12: 271-286.

Kadmon, Nirit and Fred Landman (1993). 'Any'. Linguistics and Philosophy 16: 353422.

Kaufmann, Magdalena (2012). Interpreting Imperatives. Studies in Linguistics and Philosophy 88. New York: Springer.

Kratzer, Angelika (1998). 'Scope or pseudoscope? Are there wide scope indefinites?', in Events in Grammar, S. Rothstein (ed.), Dordrecht: Kluwer.

Kratzer, Angelika and Junko Shimoyama (2002). 'Indeterminate Pronouns: The View from Japanese', in Proceedings of the Third Tokyo Conference on Psycholinguistics, Y. Otso (ed.), pp. 1-25. Tokyo: Hituzi Syobo. 
Lauer, Sven (2010). 'Some news on irgendein and algún.' Paper presented at the Workshop on Epistemic Indefinites, Göttingen, June 2010.

Portner, Paul (2007). 'Imperatives and modals'. Natural Language Semantics 15:351383.

Portner, Paul (2009). Modality. Oxford Surveys in Semantics and Pragmatics, Oxford University Press

Rawlins, Kyle (2008). (Un)Conditionals: An Investigation in the Syntax and Semantics of conditional Structures. Doctoral dissertation, University of California, Santa Cruz.

Săvescu-Ciucivara, Oana (2007). 'Oarecare Indefinites Are Not Just Any Indefinites', in Pitar Moş: A Building with a View. Papers in Honour of Alexandra Cornilescu, G. Alboiu, A. Avram, L. Avram, and D. Isac (eds.), pp. 205-225, Bucharest: Editura Universităţii din Bucureşti. 